\title{
Population dynamics and reproductive traits of the ornamental crab Porcellana sayana: implications for fishery management and aquaculture
}

\author{
J. Antonio Baeza ${ }^{1,2, *}$, Michele Furlan ${ }^{3}$, Ariádine C. Almeida ${ }^{3,4}$, \\ Samara de Paiva Barros-Alves ${ }^{3,5}$, Douglas F. R. Alves ${ }^{3,5}$, Vivian Fransozo ${ }^{3,6}$ \\ ${ }^{1}$ Smithsonian Marine Station at Fort Pierce, Fort Pierce, Florida 34949, USA \\ ${ }^{2}$ Departamento de Biología Marina, Facultad de Ciencias del Mar, Universidad Católica del Norte, Larrondo 1281, \\ Coquimbo, Chile \\ ${ }^{3}$ NEBECC (Crustacean Biology, Ecology and Culture Study Group), Departamento de Zoologia, Instituto de Biociências, \\ Universidade Estadual Paulista, Botucatu, São Paulo, CEP 18618-970, Brazil \\ ${ }^{4}$ Instituto de Biologia, Universidade Federal de Uberlândia, Campus Umuarama, Rua Ceará, s/n, Uberlândia, Minas Gerais, \\ CEP 38400-902, Brazil \\ ${ }^{5}$ Laboratório de Biologia Marinha - LabBMar, Instituto Básico de Biociências - IBB, Universidade de Taubaté - UNITAU, \\ Av. Tiradentes, 500, Taubaté, São Paulo, CEP 12.030-180, Brazil \\ ${ }^{6}$ Departamento de Ciências Naturais - Zoologia, Universidade Estadual do Sudoeste da Bahia (UESB), Campus de Vitória da \\ Conquista, Bairro Universidade, CEP 45031-900 Vitória da Conquista, Bahia, Brazil
}

\begin{abstract}
We report on the population dynamics and reproductive traits of an ornamental crustacean, the spotted porcelain crab Porcellana sayana. Reproductive biology was examined between January 1998 and December 1999 at 3 different bays off Ubatuba, southeastern Brazil. The growth curves for males and females are described by the equations carapace width at age $t\left(\mathrm{CW}_{t}\right)$ $=9.42\left[1-\mathrm{e}^{-0.0085(t-0.1972)}\right]$ and $\mathrm{CW}_{t}=8.35\left[1-\mathrm{e}^{-0.0097(t-0.5411)}\right]$, respectively. Males and females of $P$. sayana grew at similar rates and attained similar average and final body sizes. Longevity was estimated to be $1.48 \mathrm{yr}$ in males and $1.3 \mathrm{yr}$ in females. Reproduction was continuous but with dissimilar intensity during the study period. A reproductive peak during the warm austral spring and summer seasons was evident during 1999, but no obvious reproductive seasonality was detected during 1998. The estimated CW at first maturity in P. sayana, based on the 5 smallest ovigerous females captured during each season, varied between $4.72 \mathrm{~mm}$ (summer 1999) and $5.69 \mathrm{~mm}$ (winter 1999), with an average of $4.98 \mathrm{~mm}( \pm 0.37 \mathrm{SD})$. Recruitment intensity appears to be episodic and varied haphazardly in $P$. sayana. Sex ratio did not differ significantly from a 1:1 ratio during most of the seasons. The information generated in this study needs to be considered in assessing stocks and establishing sustainable management plans for $P$. sayana in the Caribbean, Gulf of Mexico, and western Atlantic.
\end{abstract}

KEY WORDS: Ornamental fishery $\cdot$ Aquarium trade $\cdot$ Aquaculture $\cdot$ Porcellanidae

\section{INTRODUCTION}

The ornamental fishery is a multi-million dollar industry that supports fishermen in countries with developing and developed economies and provides aquarists from around the world with a selection of

*Email: baeza.antonio@gmail.com
$>1400$ species of marine and freshwater fish, invertebrates, plants, and algae (Chapman et al. 1997, Calado et al. 2003, Bruckner 2005, Rhyne et al. 2009). Although numerous, ornamental fisheries often operate unnoticed, have received little attention, and their management is often based on limited life his- 
tory information (Rhyne et al. 2009). The exploitation of ornamentals has intensified considerably during the last decades (Calado et al. 2003, Green 2003, Gasparini et al. 2005). The industry generally relies on the harvesting of organisms from the natural envi-
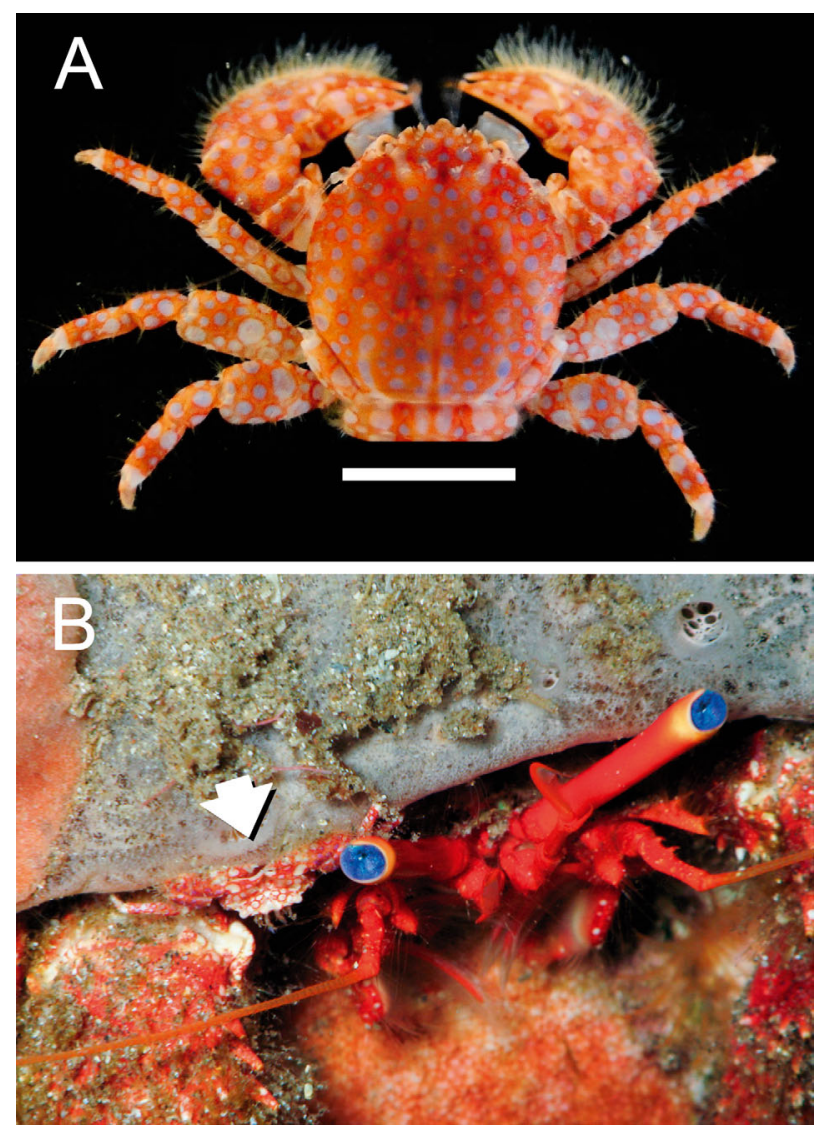

Fig. 1. Porcellana sayana. (A) Habitus and color pattern of the ornamental porcelain crab. Dorsal view. Scale bar $=5 \mathrm{~mm}$ (photo: Adilson Fransozo). (B) Typical position of P. sayana (arrow) in a shell used hermit crab, in this case Paguristes sericeus (photo: Brian Mayes) ronment, and this harvesting most likely will continue to increase during the next decades (Friedlander 2001, Wood 2001, Tlusty 2002). Therefore, it is imperative to develop a baseline of biological information to manage ornamental species in a sustainable manner (Rhyne et al. 2009).

In the central and south Atlantic, Brazil leads the export of marine ornamentals (Bruckner 2005). About 120 and 65 species of marine fish and invertebrates, respectively, are exported to Europe, USA, and Japan (Gasparini et al. 2005). Approximately $23 \%$ of the marine ornamentals extracted from intertidal and shallow subtidal habitats in the southwestern Atlantic are decapod crustaceans (Gasparini et al. 2005). Examples include hermit crabs from the genera Clibanarius, Dardanus and Petrochirus, boxer shrimps from the genus Stenopus, true crabs from the species complex Mithrax - Mithraculus and shrimps from the genus Lysmata, Thor, and Periclimenes. Also, the spotted porcelain crab Porcellana sayana is highly valued because of its aesthetic value (MatosCaraballo \& Mercado-Porrata 2007) (Fig. 1A,B).

Porcellana sayana occurs in the intertidal zone and up to depths of $\sim 92 \mathrm{~m}$ in the northwestern Atlantic (up to North Carolina in the USA), Gulf of Mexico, Caribbean Sea and southwestern Atlantic (south to Uruguay) (Williams 1984). This crab develops symbiotic associations (symbiosis here defined sensu De Bary 1879 as dissimilar organisms living together) with various hermit crabs (Haig 1956, Werding 1977, Telford \& Daxboeck 1978, Gore 1982), the spider crab Stenocionops furcata (Werding 1977), the holothurian Astichopus multifidus (Werding 1977, 1984), the 'botuto' Strombus gigas (Telford \& Daxboeck 1978), and the turtle Caretta caretta (Frick et al. 2002) (Table 1, Fig. 1B). P. sayana is gonochoric (i.e. has separate sexes) and usually lives in aggregations (of up to 14 conspecifics per host individual; Meireles \& Mante-

Table 1. Porcellana sayana. Host diversity of the ornamental porcelain crab, its position in/on the different host species and study sites. 1: Gore \& Abele (1976); 2: Gore (1982); 3: Werding (1977); 4: Telford \& Daxboeck (1978); 5: Frick et al. (2002)

\begin{tabular}{|c|c|c|c|}
\hline Dardanus venosus (H. Milne Edwards, 1848) (Anomura & Inside the shell and/or on the host & Barbados & 4 \\
\hline Dardanus fucosus Biffar \& Provenzano, 1972 (Anomura & Inside the shell and/or on the host & Colombia, Panama & 1,3 \\
\hline Paguristes grayi Benedict, 1901 (Anomura) & Inside the shell and/or on the host & Barbados & 4 \\
\hline Paguristes tortugae Schmitt, 1933 (Anomura) & Inside the shell and/or on the host & Colombia & 3 \\
\hline Petrochirus diogenes (Linnaeus, 1758) (Anomura) & Inside the shell and/or on the host & Barbados, Venezuela & 2,4 \\
\hline Strombus gigas Linnaeus, 1758 (Gastropoda) & \multirow{2}{*}{$\begin{array}{l}\text { On inner surface of the operculum or close to it } \\
\text { Posterior of the carapace }\end{array}$} & Barbados & 4 \\
\hline Caretta caretta (Linnaeus, 1758) (Reptilia) & & Georgia, USA & 5 \\
\hline
\end{tabular}


latto 2008) in the same shell occupied by hermit crabs (Telford \& Daxboeck 1978, Meireles \& Mantelatto 2008) or perched on the body of their crab, holothurian, and turtle hosts (Telford \& Daxboeck 1978, Werding 1984, Frick et al. 2002). Laboratory experiments have shown that $P$. sayana is chemically attracted to Calliactis tricolor, a sea anemone that is usually attached to the external surface of the shell used by hermit crabs (Brooks \& Rittschof 1995, LópezVictoria et al. 2004). Thus, P. sayana might also benefit from sea anemones, as suggested before for various other porcelain crabs (Petrolisthes spinifrons: Baeza et al. 2001, 2010, Baeza \& Asorey 2012; Neopetrolisthes spp.: Osawa \& Fujita 2001, Osawa \& McLaughlin 2010). Although, our knowledge on the biology of $P$. sayana has improved during the last decades, studies on population dynamics as well as on population- and individual-level reproductive traits are lacking in this species. For instance, nothing is known about growth, recruitment, size at first sexual maturity, sex ratio, and reproductive seasonality of this porcelain crab, although this kind of life history information is most critical for managing any ornamental fishery with the goal of sustainability (Rhyne et al. 2009).

The aim of this study was to investigate the reproductive biology of the ornamental crab Porcellana sayana. We examined population dynamics, growth, recruitment intensity, size at first sexual maturity, sex ratio, and reproductive seasonality of this species in Ubatuba, southeastern coast of Brazil. We tested the hypothesis of continuous reproduction of $P$. sayana in this subtropical locality, as environmental conditions prevailing at these latitudes are expected to favor

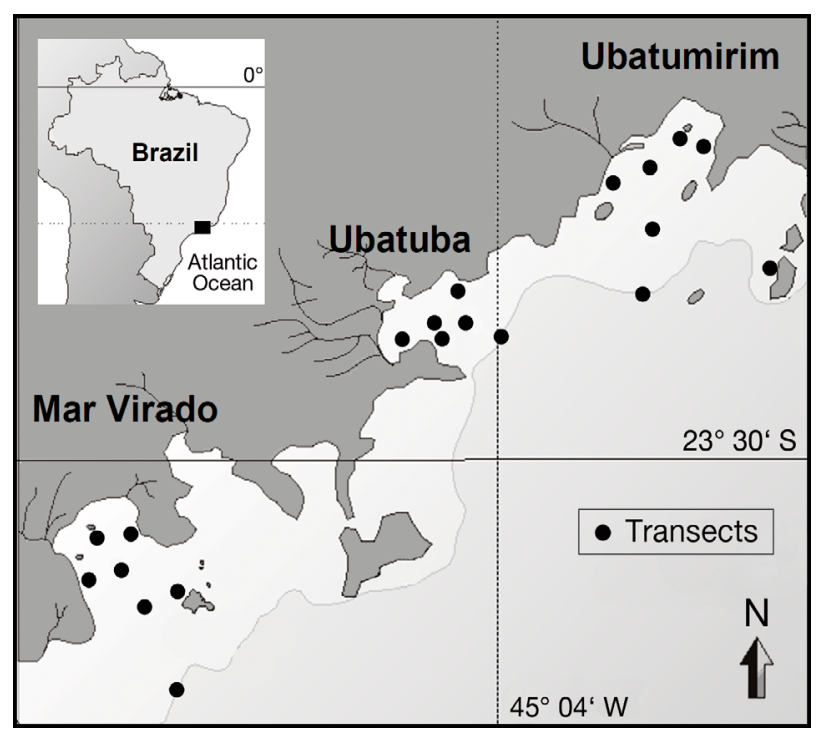

Fig. 2. Porcellana sayana. Sampling area and transects year-round gonad development and larval production in marine invertebrates (Sastry 1983). This and future studies on the reproductive biology of this species will form the baseline for models aimed at assessing the stock condition and sustainability of this valued ornamental crustacean.

\section{MATERIALS AND METHODS}

\section{Study sites and sampling methods}

Specimens of Porcellana sayana and the hermit crabs harboring them (i.e. Dardanus insignis, Petrochirus diogenes and other unidentified species) were collected monthly from January 1998 to December 1999 at Ubatumirim (UBM, 233 $\left.37^{\prime} \mathrm{S}, 44^{\circ} 53^{\prime} \mathrm{W}\right)$, Ubatuba (UBA, $23^{\circ} 27^{\prime} \mathrm{S}, 45^{\circ} 00^{\prime} \mathrm{W}$ ) and Mar Virado (MV, $\left.23^{\circ} 34^{\prime} \mathrm{S}, 45^{\circ} 09^{\prime} \mathrm{W}\right)$ bays, Ubatuba region, northern coast of São Paulo State, Brazil (Fig. 2). Sampling was conducted with a fishing boat using 2 rig nets (15 and $10 \mathrm{~mm}$ mesh diameter at the body and cod end of the net, respectively) that were deployed at depths varying between 5 and $17 \mathrm{~m}$ in each bay (Fig. 2). After each trawl ( $\mathrm{n}=6$ or 7 per month and bay, lasting 30 min each), porcelain and hermit crabs were collected from the nets at the boat desk. Porcelain crabs were usually found within shells also occupied by hermit crabs. Nonetheless, some individuals of $P$. sayana were also observed crawling freely among the net treads. Most probably, these roaming crabs abandoned their host individuals during trawling. All collected hermit and porcelain crabs were placed inside ice chests (filled with ice) for transportation to the laboratory.

In the laboratory, the shells occupied by hermit crabs were gently cracked open with a small hammer and all porcelain crabs were collected from within the shells and from the body of hermit crabs. Next, each porcelain crab was measured (carapace width, CW $[\mathrm{mm}]$ ) under a Zeiss dissecting microscope (precision $=0.01 \mathrm{~mm}$ ) and sexed according to the position of the genital openings (gonopores) and morphology and number of pleopods. Males have gonopores at the base of the coxae of the 5th pair of pereopods, and a single pair of pleopods modified as gonopods are present on the 2nd abdominal somite. Females have gonopores at the base of the 3rd pair of pereopods and well-developed and setose pleopods on each abdominal somite 3 to 5 (Osawa \& McLaughlin 2010). Each female was classified according to the presence or absence of embryos (ovigerous or nonovigerous) underneath the abdomen. 


\section{Population dynamics}

Specimens of Porcellana sayana, collected from all 3 bays, were pooled together for the analysis of population dynamics because the number of crabs collected in each bay was low, and there was no major difference in the size-frequency distribution of $P$. sayana among the studied localities (minimummaximum, average \pm SD CW; UBM: 2.14-11.7 mm, $5.4 \pm 1.2 \mathrm{~mm}$; UBA: $2.52-9.18 \mathrm{~mm}, 5.7 \pm 1.3 \mathrm{~mm}$; MV: 2.44-9.56 mm, $5.6 \pm 1.2 \mathrm{~mm})$. Size-frequency distributions were constructed using $0.7 \mathrm{~mm} \mathrm{CW}$ intervals for both males and females in order to analyze the population dynamics of this species.

Modal groups were determined separately for males and females using monthly size-frequency distributions with the software PeakFIT (PeakFIT v.4.06 SPSS for Windows, Copyright 1991-1999, AISN Software). Different numbers of peaks representing different cohorts were fitted to the observed sizefrequency distributions using an automated least squares fitting procedure (Automatic Peak Fitting Detection and Fitting, Method I - Residual).

Next, growth parameters were fitted to our dataset using the von Bertalanffy (1938) growth curve:

$$
\mathrm{CW}_{t}=\mathrm{CW}_{\infty}\left[1-\mathrm{e}^{-K\left(t-t_{0}\right)}\right]
$$

where $\mathrm{CW}_{t}$ is the average $\mathrm{CW}$ estimated at age $t(\mathrm{~d})$; $\mathrm{CW}_{\infty}$ is the asymptotic maximum $\mathrm{CW}_{;} K$ is a growth constant defining how quickly $\mathrm{CW}_{\infty}$ is reached, and $t_{0}$ is the theoretical age at which crabs would have zero CW. Also, we used trial-and-error iterations to estimate the values for $K$ and $t_{0}$. Growth curves for both males and females were estimated using cohort (modal) progression through time. To estimate growth parameters, all the cohorts were fitted to the von Bertalanffy growth model using an automated least squares fitting procedure (SOLVER, software EXCEL).

Lastly, growth curves were compared between males and females using an F-test (Cerrato 1990, Chen et al. 1992) and longevity $\left(t_{\max }\right)$ was calculated using the inverse von Bertalanffy growth function:

$$
t_{\max }=t_{0}-(1 / K) \ln \left[1-\left(\mathrm{CW}_{t} / \mathrm{CW}_{\infty}\right)\right]
$$

\section{Population reproductive parameters}

Four different population parameters were calculated on a per season basis: proportion of ovigerous females, size at first maturity, recruitment intensity, and sex ratio. We grouped our data into seasons given the relatively low number of crabs captured per month. The proportion of ovigerous females was estimated as the number of females carrying eggs beneath the abdomen relative to the total number of females larger than the minimum size of female maturity (i.e. excluding juvenile females, see below). We compared the proportion of ovigerous females among seasons using using Goodman's test, which analyzes the contrasts between and within multinomial proportions ( $\alpha=0.05$ ) (Goodman 1965, Curi \& Moraes 1981). In females, size at first maturity $\left(\mathrm{CW}_{50}\right)$ is usually estimated as the size at which the probability of carrying eggs beneath the abdomen is 0.5 using logistic regression (Wilson \& Hardy 2002). Unfortunately, the large number of non-ovigerous females observed during this study (see 'Results') resulted in considerable overestimation of $\mathrm{CW}_{50}$ when using logistic regression (data not shown). Thus, we used the CW of the 5 smallest ovigerous females observed during each season as a proxy for size at first maturity. We compared size at first maturity among seasons using a 1-way ANOVA (Zar 1999). Recruitment intensity was estimated as the proportion of juveniles in the population. Male and female crabs with a CW smaller than that of the smallest ovigerous female during each season were classified as juveniles. We assumed that males and females reached maturity at the same body size as no significant difference in growth between the 2 sexes was found (see 'Results'). We compared the proportion of juveniles among seasons using Goodman's test, which analyzes the contrasts between and within multinomial proportions $(\alpha=0.05)$ (Goodman 1965, Curi \& Moraes 1981). Sex ratio was estimated as the quotient between the number of males and the number of males plus females in the population. Thus, sex ratio values higher or lower than 0.5 indicate population skews toward males or females, respectively. For each season, we tested deviations from a 1:1 sex ratio using a binomial test (Wilson \& Hardy 2002).

\section{RESULTS}

A total of 1322 porcelain crabs (637 males and 685 females) were analyzed during the present study. Population numbers declined in 1998 compared to 1999, but no evident seasonal cycle in crab abundance was noticed (Fig. 3A). The body size of the smallest and largest crab observed during the sampling period was 2.14 and $11.7 \mathrm{~mm} \mathrm{CW}$ (both crabs were male). Sizefrequency distribution analysis demonstrated that crabs from all body sizes and sexes were intermittently present year round at the study sites (Figs. 4 \& 5). 

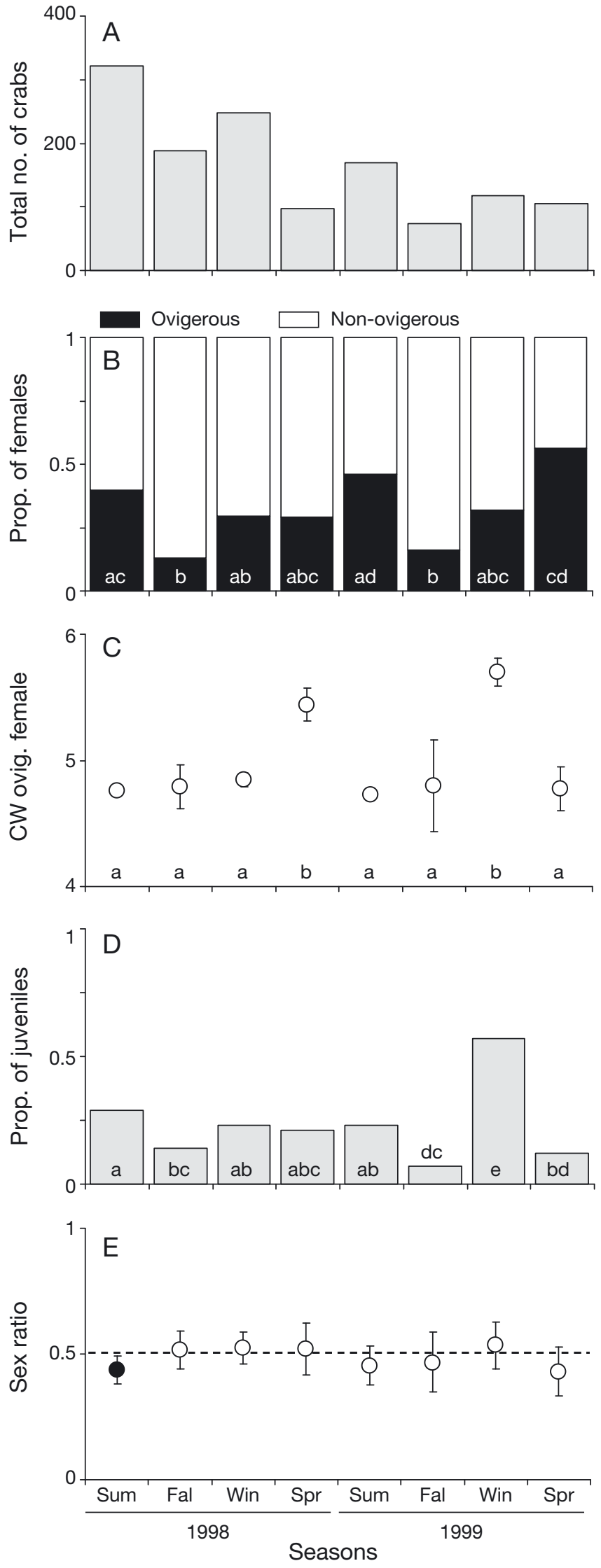

\section{Population dynamics}

Modal progression analysis detected 5 cohorts in males and 6 cohorts in females (Figs. 4 \& 5). For each sex, growth parameters fitted to the data using the von Bertalanffy equation for the different cohorts are shown in Table 2. The growth curves for males and females are described by the equations $\mathrm{CW}_{t}=9.42\left[1-\mathrm{e}^{-0.0085(t-0.1972)}\right]$ and $\mathrm{CW}_{t}=8.35$ $\left[1-\mathrm{e}^{-0.0097(t-0.5411)}\right]$ (Fig. 6), respectively. According to these equations, males reach a larger asymptotic size than females (female asymptotic size was $12.8 \%$ smaller than the male asymptotic size) and have a smaller growth coefficient. Nonetheless, the growth curves did not differ significantly between males and females of Porcellana sayana $\left(F_{3,61}=\right.$ $2.76, \mathrm{p}=0.0640)$. Also, no statistically significant differences were detected between the average body size of males and females in the population (average $\pm \mathrm{SD}$; males $5.54 \pm 1.37$; females: $5.50 \pm$ 1.16 ; $t$-test: $\left.t_{1,1320}=0.618, \mathrm{p}=0.54\right)$.

For each sex, the asymptotic size estimated with the von Bertalanffy equation was slightly smaller (males: $9.42 \mathrm{~mm} \mathrm{CW}, 19.5 \%$ smaller than largest observed crab; females: $8.35 \mathrm{~mm} \mathrm{CW}, 7.8 \%$ smaller than largest observed crab) than the size of the largest male and female crab observed during the entire study period (males: $11.7 \mathrm{~mm} \mathrm{CW}$; females: $9.06 \mathrm{~mm} \mathrm{CW}$ ).

Longevity was estimated to be $1.48 \mathrm{yr}$ in males and $1.3 \mathrm{yr}$ in females. The age estimated for the smallest recorded male (2.14 $\mathrm{mm} \mathrm{CW}$ ) was $31 \mathrm{~d}$, while the age of the smallest female $(2.44 \mathrm{~mm} \mathrm{CW})$ was estimated to be $36 \mathrm{~d}$.

\section{Population reproductive parameters}

A total of 180 out of 685 females carried embryos beneath the abdomen during the study period. The percentage of adult ovigerous females varied between $13 \%$ during fall 1998 and $56 \%$ during spring

Fig. 3. Porcellana sayana. (A) Abundance (no. of crabs collected per season), (B) proportion of adult ovigerous females, $(C)$ size (mean \pm SE) (carapace width, CW) at first maturity of females, (D) proportion of juveniles, and (E) sex ratio (estimate $\pm \mathrm{SE}$ ) during different seasons of the years 1998 and 1999. In (B), (C), and (D), different letters indicate significant differences between seasons. In (D), crabs with a CW smaller than that of the smallest ovigerous female were considered juveniles during each season. In (E), the black circle indicates a deviation from a 1:1 sex ratio. Sum: Summer, Fal: Fall, Win: Winter, Spr: Spring 


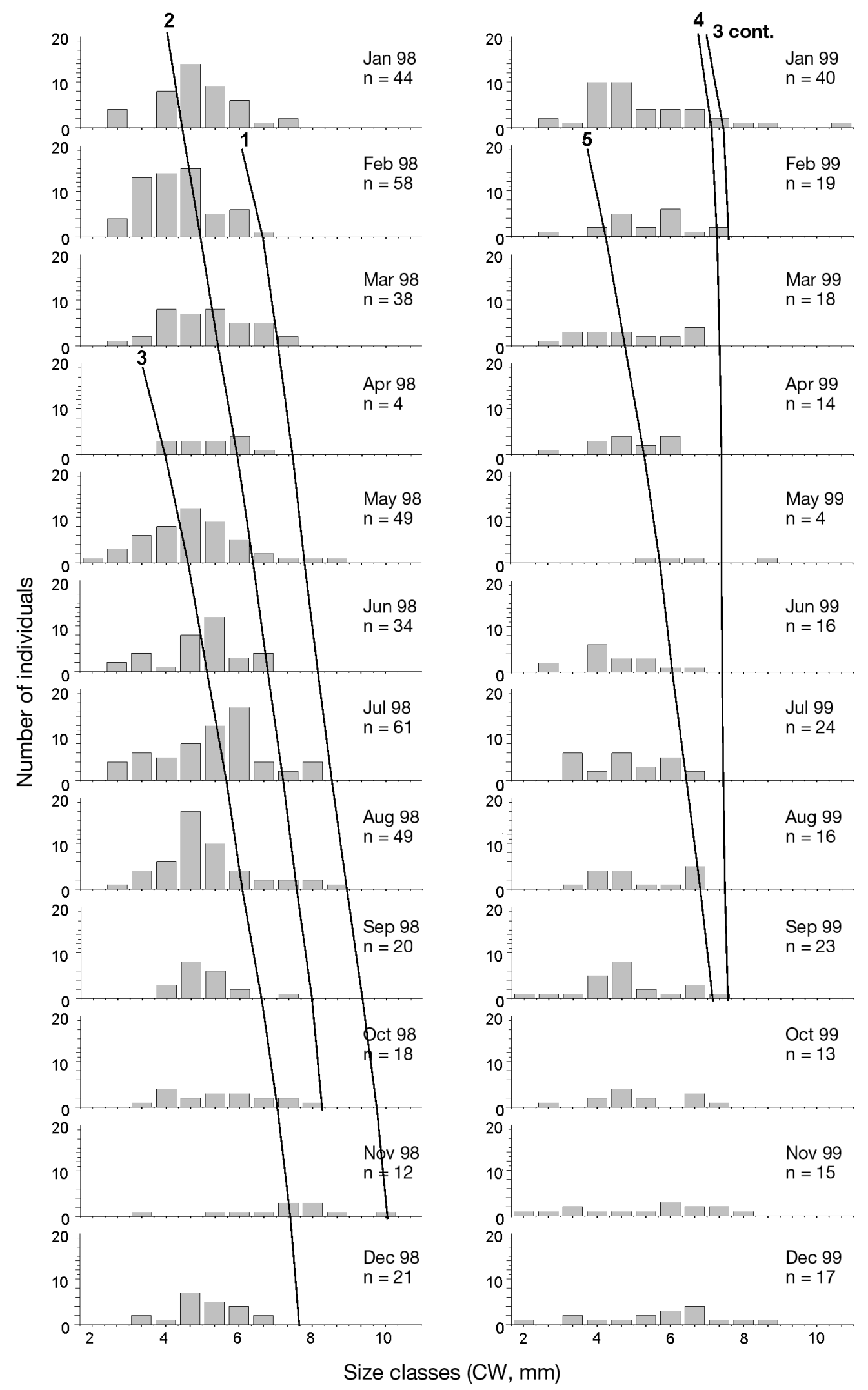

Fig. 4. Porcellana sayana. Size-frequency distribution and modal progression analysis of cohorts in males in the Ubatuba region, southeastern Brazil, during 1998 and 1999. Samples from the 3 different bays were combined for the analysis of population dynamics. Lines represent the different cohorts $(n=5)$. CW: carapace width 


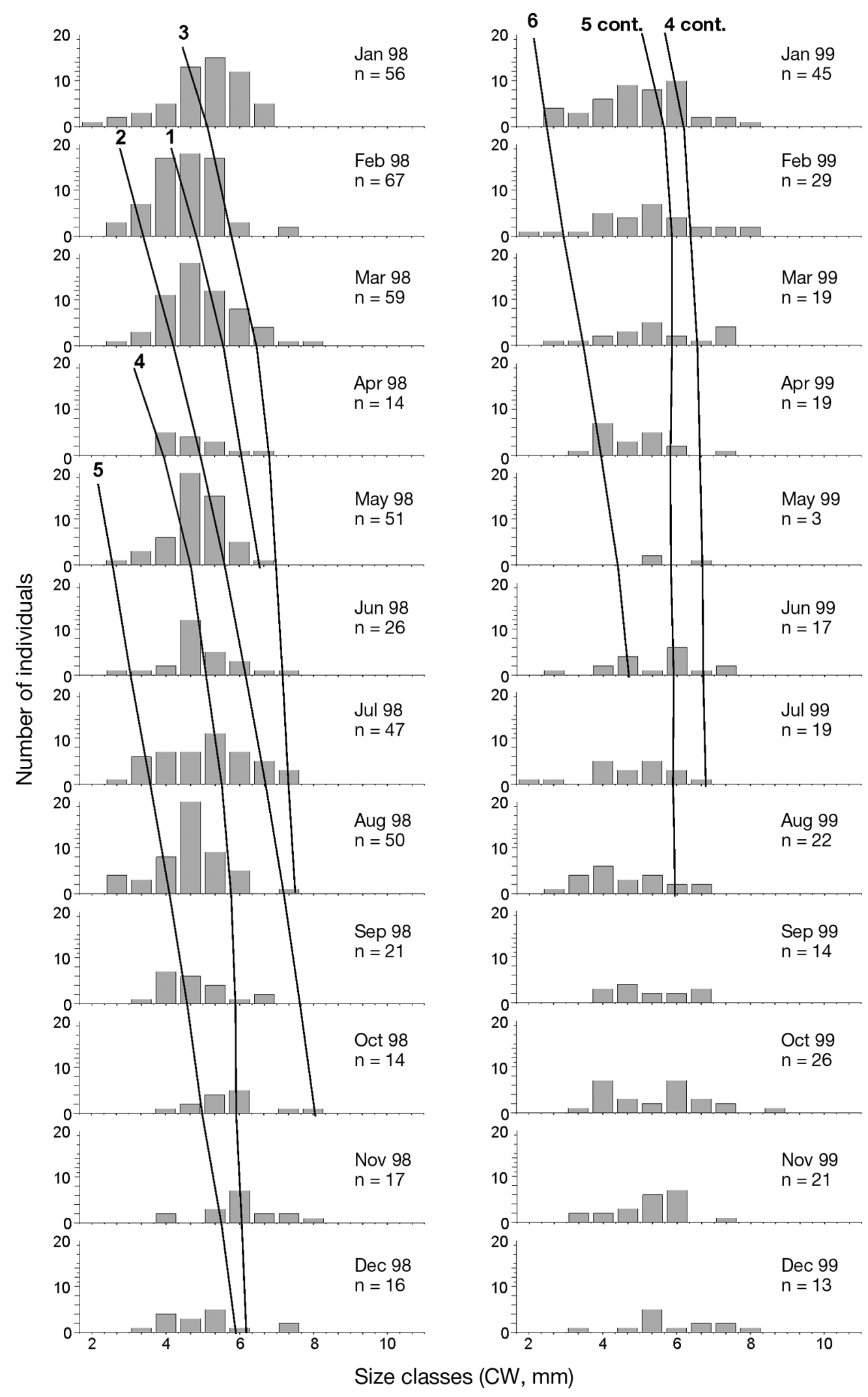

Fig. 5. Porcellana sayana. Size-frequency distribution and modal progression analysis of cohorts in females in the Ubatuba region, southeastern Brazil, during 1998 and 1999. Samples from the 3 different bays were combined for the analysis of population dynamics. Lines represent the different cohorts $(n=6)$. CW: carapace width 
1999 , with an average $( \pm \mathrm{SD})$ of $33 \%( \pm 14 \%)$. Significant differences in the proportion of ovigerous females were observed among seasons $(p<0.05$, Fig. 3B). During 1999, the greatest relative abundance of ovigerous females occurred during summer and spring months. This seasonal reproductive pattern was not obvious during 1998. Nonetheless, brooding females were significantly less abundant during fall 1998 than during summer of the same year (Fig. 3B).

The estimated CW at first maturity in Porcellana sayana, based on the 5 smallest ovigerous females captured during each season, varied between $4.72 \mathrm{~mm}$ (summer 1999) and $5.69 \mathrm{~mm}$ (winter 1999), with an average $( \pm$ SD) of $4.98 \mathrm{~mm}( \pm 0.37)$. Significant differences in the size at first maturity were observed among seasons (1-way ANOVA [after logarithmic transformation of the dependent variable to fulfill the test assumptions], $F_{7,39}=4.74, \mathrm{p}=0.001$, Fig. $3 \mathrm{C}$ ). Size at first maturity was reached at larger body sizes during spring 1998 and winter 1999 than during the rest of the seasons (a posteriori least significant difference, LSD, test, $\mathrm{p}<0.05$ ) (Fig. 3C).

Recruitment intensity varied considerably through the sampling period. The relative abundance of juveniles (crabs with a CW smaller than that of the smallest ovigerous female during each season) ranged from $7 \%$ in fall 1999 to $57 \%$ in winter 1999 , with an average $( \pm$ SD) of $23 \%( \pm 15 \%)$. Significant differences in the relative abundance of juveniles were observed among seasons ( $p<$ 0.05, Fig. 3D). However, no evident seasonal recruitment pattern was observed during the study period (Fig. 3D).

Table 2. Porcellana sayana. Growth parameters of the ornamental crab in this study. $\mathrm{CW}_{\infty}$ : asymptotic size (carapace width), $K$ : growth constant, $t_{\max }$ l longevity

\begin{tabular}{|lccc|}
\hline $\begin{array}{l}\text { Sex } \\
\text { Cohort }\end{array}$ & $\mathrm{CW}_{\infty}(\mathrm{mm})$ & $K$ & $t_{\max }(\mathrm{yr})$ \\
\hline Male & & & \\
1 & & & \\
2 & 11.01 & 0.008 & 1.42 \\
3 & 9.54 & 0.007 & 1.62 \\
4 & 9.12 & 0.008 & 1.56 \\
5 & 8.03 & 0.009 & 1.26 \\
Female & 8.38 & 0.008 & 1.41 \\
1 & & & \\
2 & 9.10 & 0.012 & 1.04 \\
3 & 8.04 & 0.011 & 1.10 \\
4 & 9.63 & 0.009 & 1.34 \\
5 & 7.35 & 0.011 & 1.08 \\
6 & 6.47 & 0.010 & 1.26 \\
& 6.16 & 0.009 & 1.37 \\
\hline
\end{tabular}

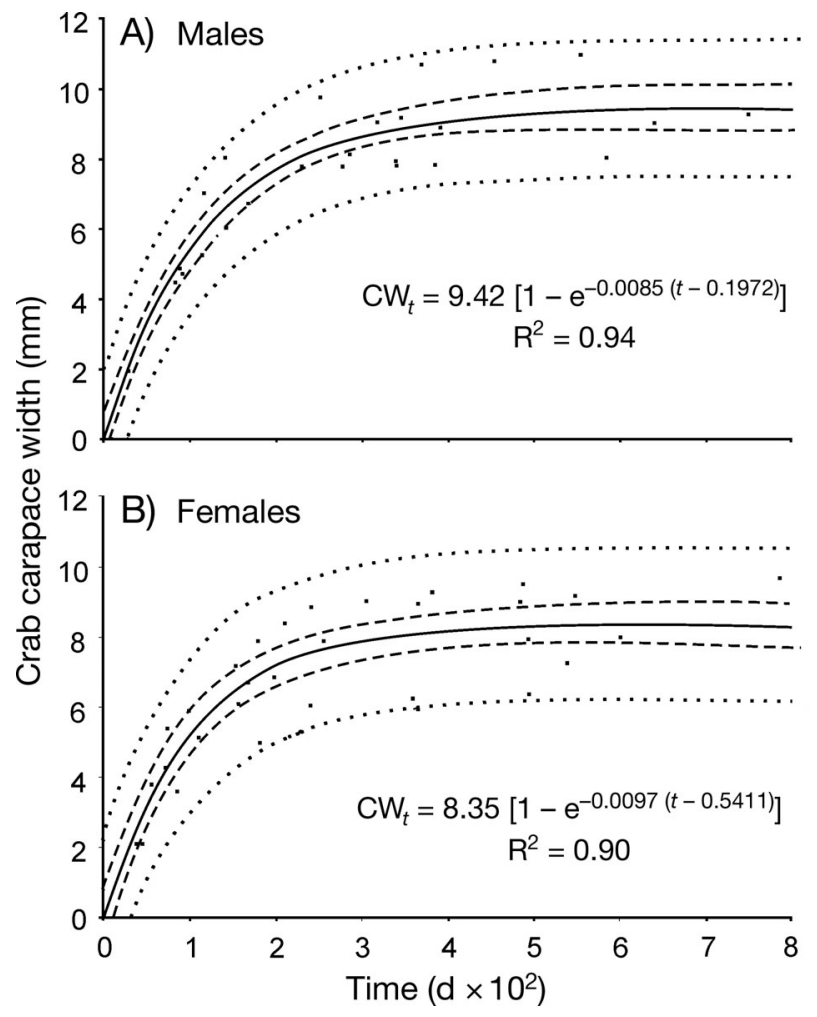

Fig. 6. Porcellana sayana. Growth curves and von Bertalanffy equations. Center line: mean; dotted lines: prediction intervals (95\%); dashed lines: confidence interval (95\%). Individual points represent modal carapace width $(\mathrm{CW})$ derived from size-frequency distributions

The proportion of males varied between 0.43 and 0.53 with a mean $( \pm \mathrm{SD})$ of $0.48( \pm 0.04)$. Sex ratio did not differ significantly from a 1:1 ratio during most of the seasons (binomial test, $\mathrm{p}>0.05$ ). Only during summer 1998 did the sex ratio deviate significantly from 1:1 and was slightly skewed toward females (males : females $=1: 1.3 ; \mathrm{p}=0.02$ ) (Fig. 3E).

\section{DISCUSSION}

\section{Growth and sexual dimorphism}

In Ubatuba, males and females of Porcellana sayana grew at similar rates during the study period. In other crustaceans, observed differences in growth rate between males and females are usually attributed to sex-specific resource allocation strategies (e.g. growth versus gamete production) (Pinheiro \& Hattori 2006, Keunecke et al. 2007). Males usually invest more energy into somatic growth than females because body size usually translates into increased 
male competitive ability and access to receptive females. In turn, females allocate most of their energy into egg production (Hartnoll 1982). In P. sayana, separate measurements of the growth rate for males and females do not denote dissimilar resource allocation strategies between the sexes.

In Porcellana sayana, males and females grew at similar rates and also attained similar average body sizes, in agreement with that reported before for 2 other porcelain crabs (Pachycheles monilifer: Fransozo \& Bertini 2001; Allopetrolisthes [=Petrolisthes] spinifrons: Baeza \& Asorey 2012). Males of P. sayana attained larger observed and expected asymptotic body sizes than females. However, the fact that males and females grew at similar rates and the lack of differences in average body sizes between the sexes strongly argue in favor of sexual monomorphism in this species. However, most porcelain crabs are sexually dimorphic; males attain larger average and final body sizes than females (Smaldon 1973, Ahmed \& Mustaquim 1974, Miranda \& Mantelatto 2009, Baeza \& Asorey 2012). For instance, in the sexually dimorphic Liopetrolisthes (= Petrolisthes) mitra, the average body size of males is larger than that of females, and the maximum body size attained by males is $\sim 30 \%$ larger than that attained by females (Baeza \& Asorey 2012). In the sexually homomorphic Allopetrolisthes (= Petrolisthes) spinifrons, low intensity of male sexual competition dictated by infrequent encounter rates among conspecifics appears to explain the absence of body size dimorphism (Baeza \& Asorey 2012). In P. sayana, intra- and inter-sex interactions are expected to be recurrent because this crab is gregarious (Meireles \& Mantelatto 2008). Group living is expected to increase the frequency of social interactions, including male-male competition that, in turn, should favor sexual selection and sexual dimorphism in P. sayana (Baeza \& Asorey 2012). The conditions explaining the absence of sexual dimorphism in the gregarious $P$. sayana deserve more attention.

\section{Breeding seasonality}

Porcellana sayana reproduces continuously but with dissimilar intensity during the year. A reproductive peak during spring and summer seasons was detected during 1999. However, reproductive seasonality was not evident during 1998. The reproductive pattern of $P$. sayana during 1999 agrees with that reported before for other crustaceans from the same subtropical region (e.g. Oliveira \& Masu- nari 1995, Miranda \& Mantelatto 2009) but differs from that reported for crustaceans from lower tropical and higher temperate latitudes. In crustaceans from temperate regions, including porcelain crabs, reproduction is highly seasonal and halts during the coldest months of the year (Antezana et al. 1965, Gebauer et al. 2007). In turn, reproduction is continuous and occurs with similar intensity during the year in crustaceans from tropical latitudes (e.g. Petrolisthes politus: Scelzo 1985; Hippolyte curacaoensis, Processa bermudensis and Thor manningi: Bauer 1989). The absence of reproductive seasonality in $P$. sayana during 1998 agrees with that reported before for crustaceans from tropical latitudes. Thus, $P$. sayana appears to exhibit a 'mixed' subtropical/ tropical reproductive pattern in Ubatuba. The relative importance that ecological conditions (e.g. primary productivity, temperature, and food availability for larvae) might have in shaping reproductive activity in $P$. sayana and other subtropical marine invertebrates remain to be addressed.

In Porcellana sayana, recruitment intensity was not seasonal. Indeed, recruitment in $P$. sayana appeared to be episodic rather than continuous, and the relative abundance of juveniles in the population increased and decreased rather haphazardly during the year. It is commonly assumed that periods of reproduction and recruitment should be time-correlated, i.e. seasonal recruitment when reproduction is limited to some periods of the year and continuous recruitment when reproduction takes place throughout the entire year (Bauer 1989). Nonetheless, a variety of environmental conditions might influence recruitment intensity in natural populations, including local oceanographic conditions (Shanks et al. 2003). Whether or not local oceanographic processes influence recruitment intensity in Ubatuba via export/import of larvae from/to the region remain to be studied.

Temporal variability in size at first maturity has rarely been studied in marine invertebrates (e.g. Baeza et al. 2010). Recent studies have shown that sexual maturity is attained early in life during warmer months compared to colder months of the year in other temperate and subtropical crustaceans (Almeida et al. 2012, Onaga et al. 2012). Laboratory experiments have shown that temperature and photoperiod affect the timing of maturity in some crustaceans (Bauer 2002, Baldwin \& Bauer 2003). For instance, in the shrimp Lysmata wurdemanni, small individuals speed up female reproduction under conditions of high water temperature and long day length, which in turn, emulate natural late spring and 
summer conditions (Bauer 2002). In general, the haphazard shifts in size at first maturity observed in Porcellana sayana do not agree with the effect of abiotic conditions in the timing of sex maturity in other crustaceans. We argue in favor of studies constructing age-structured model to evaluate the effect of variability in size at maturity on population assessments of $P$. sayana.

In Porcellana sayana, equal sex ratios were observed during most of the study period, in agreement with those reported for other porcelain crabs from the same region (e.g. Petrolisthes armatus: Miranda \& Mantelatto 2009) and from temperate regions (Petrolisthes laevigatus: Gebauer et al. 2007). For species with separate sexes like $P$. sayana, sex allocation theory predicts equal sex ratios, as parents should produce an equal number of male and female offspring because of frequency-dependent selection against the more common sex in the population (Fisher 1930). Thus, our results in P. sayana supports predictions central to sex allocation theory. Nonetheless, in various other crustaceans from the same region, sex ratio unbalances have been reported (Almeida et al. 2012, and references therein). Major causes for imbalances in sex ratio among marine invertebrates include sex-specific growth and/or mortality rates (Wenner 1972), gender-dependant migration (Wenner 1972), and mating system with intense male sexual competition (Baeza \& Piantoni 2010, Baeza \& Díaz-Valdés 2011, Ocampo et al. 2012). Our study has shown that longevity, mortality, and growth rates are not sex-specific in this species. Also, crab switching among host individuals does not appear to be sex-dependant in P. sayana (Meireles \& Mantelatto 2008). The mating system of $P$. sayana deserves more attention. Yet, mating interactions in this crab do not appear to affect the sex ratio, in contrast to that which has been reported for other symbiotic crustaceans (Baeza \& Díaz-Valdés 2011, Ocampo et al. 2012).

\section{Implications for fisheries management and aquaculture}

There is an urgent need for basic information on the life history and population dynamics of marine ornamentals (Friedlander 2001, Wood 2001, Tlusty 2002, Gasparini et al. 2005). Our study has improved our understanding of the reproductive biology of an ornamental invertebrate in the Caribbean and western Atlantic. The absence of evident reproductive peaks in Porcellana sayana during one out of 2 consecutive years suggests that the closing of the fishing season during the spring and/or summer seasons might not necessarily be an efficient measure for the sustainable management of this ornamental fishery in the southwestern Atlantic. Instead, a legal minimum size for extraction of crabs might represent an appropriate fishing measure (e.g. as in the spiny lobster Panulirus argus: Florida FWC unpubl.). Due to its symbiotic lifestyle, collections of $P$. sayana most commonly involve breaking the shells occupied by the hermit crab hosts. Thus, any management of $P$. sayana should also consider the direct and indirect impacts experienced by the hermit crab species that serve as hosts to $P$. sayana.

The short larval development of Porcellana sayana (only 2 zoea stages, Hernández et al. 1998) implies that this crab is a good candidate for intensive laboratory culturing. This study has generated information on size at first maturity and growth schedules for both males and females that should help in optimizing laboratory-rearing protocols. Yet, more information on the fecundity, reproductive output, and larval and adult food requirements are needed to improve laboratory production (see Reid \& Corey 1991).

Lastly, this study reported on the reproductive biology of Porcellana sayana during the years 1998 and 1999. Importantly, high rates of exploitation can drastically alter the age/size structure and breeding structure of exploited populations at short time scales (Heino \& Godo 2002). Unfortunately, we know nothing about the intensity of exploitation of $P$. sayana in the western Atlantic. Nonetheless, many of the reproductive parameters herein described for P. sayana might no longer apply to contemporary populations of the same species in both Brazil and other geographical areas (e.g. Florida, USA, Puerto Rico). Additional studies on the reproductive ecology of $P$. sayana in different geographical areas throughout the Caribbean and western Atlantic are warranted, as these might help us to understand the effect of fishing pressure in the life history of this crab and other ornamental marine invertebrates.

Acknowledgements. We are grateful to the Fundação de Amparo à Pesquisa do Estado de São Paulo (FAPESP) for financial support (Projects \#97/12106-8, \#97/12108-6, and \#97/12107-0). We are very much indebted to Dr. A. Fransozo and Dr. M. L. Negreiros-Fransozo for their constructive comments on earlier drafts of this manuscript and to our NEBECC coworkers for their help during the fieldwork. J.A.B. was partially funded by the Florida Fish and Wildlife Conservation Commission (contract 103232 to Don C. Behringer and J.A.B.) while writing this manuscript. All sampling in this study was conducted in compliance with applicable Brazilian state and federal laws. This is SMSFP contribution no. 909. 


\section{LITERATURE CITED}

Ahmed M, Mustaquim J (1974) Population structure of four species of porcellanid crabs (Decapoda: Anomura) occurring on the coast of Karachi. Mar Biol 26:173-182

Almeida AC, Baeza JA, Fransozo V, Castilho AL, Fransozo A (2012) Reproductive biology and recruitment of Xiphopenaeus kroyeri in a marine protected area in the western Atlantic: implications for resource management. Aquat Biol 17:57-69

Antezana T, Fagetti E, Lopez MT (1965) Observaciones bioecológicas en decápodos comunes de Valparaíso. Rev Biol Mar 12:1-60 (in Spanish with English abstract)

> Baeza JA, Asorey C (2012) Testing the role of male-male competition in the evolution of sexual dimorphism: a comparison between two species of porcelain crabs. Biol J Linn Soc 105:548-558

- Baeza JA, Díaz-Valdés M (2011) The symbiotic shrimp Ascidonia flavomaculata lives solitarily in the tunicate Ascidia mentula: implications for its mating system. Invertebr Biol 130:351-361

> Baeza JA, Piantoni C (2010) Sexual system, sex ratio and group living in the shrimp Thor amboinensis (De Man): relevance to resource-monopolization and sex-allocation theories. Biol Bull 219:151-165

Baeza JA, Stotz W, Thiel M (2001) Life history of Allopetrolisthes spinifrons, a crab associate of the sea anemone Phymactis clematis. J Mar Biol Assoc UK 81:69-76

Baeza JA, Braga AA, López-Greco LS, Perez E, NegreirosFransozo ML, Fransozo A (2010) Population dynamics, sex ratio and size at sex change in a protandric simultaneous hermaphrodite, the spine shrimp Exhippolysmata oplophoroides. Mar Biol 157:2643-2653

- Baldwin AP, Bauer RT (2003) Growth, survivorship, life span, and sex change in the hermaphroditic shrimp Lysmata wurdemanni (Decapoda: Caridea: Hippolytidae). Mar Biol 143:157-166

$>$ Bauer RT (1989) Continuous reproduction and episodic recruitment in nine shrimp species inhabiting a tropical seagrass meadow. J Exp Mar Biol Ecol 127:175-187

> Bauer RT (2002) Test of hypotheses on the adaptive value of an extended male phase in the hermaphroditic shrimp Lysmata wurdemanni (Caridea: Hippolytidae). Biol Bull 203:347-357

Brooks WR, Rittschof D (1995) Chemical detection and hos selection by the symbiotic crab Porcellana sayana. Invertebr Biol 114:180-185

> Bruckner AW (2005) The importance of the marine ornamental reef fish trade in the wider Caribbean. Rev Biol Trop 53(Suppl1):127-137

> Calado R, Lin J, Rhyne AL, Araújo R, Narciso L (2003) Marine ornamental decapods - popular, pricey, and poorly studied. J Crustac Biol 23:963-973

Cerrato RM (1990) Interpretable statistical tests for growth comparisons using parameters in the von Bertalanffy equation. Can J Fish Aquat Sci 47:1416-1426

Chapman FA, Fitz-Coy SA, Thunberg EM, Adams CM (1997) United States of America trade in ornamental fish. J World Aquacult Soc 28:1-10

> Chen D, Jackson A, Harvey HH (1992) A comparison of von Bertalanffy and polynomial functions in modelling fish growth data. Can J Fish Aquat Sci 49:1228-1235

Curi PR, Moraes RV (1981) Associação, homogeneidade e contrastes entre proporções em tabelas contendo distribuições multinomiais. Cienc Cult 33:712-722 (in Por- tuguese with English abstract)

De Bary A (1879) Die Erscheinung der Symbiose: Vortrag gehalten auf der Versammlung Deutscher Naturforscher und Aerzte zu Cassel Strassburg. Verlag von Karl J. Trübner, Strasburg

Fisher RA (1930) The genetical theory of natural selection. Doven, New York, NY

Fransozo A, Bertini G (2001) Population structure and breeding period of Pachycheles monilifer (Dana) (Anomura, Pocellanidae) inhabiting sabellarid reefs from littoral coast of São Paulo state, Brazil. Rev Bras Zool 18: 197-203

Frick MG, Williams KL, Veljacic DC (2002) New records of epibionts from loggerhead sea turtles Caretta caretta (L). Bull Mar Sci 70:953-956

Friedlander AM (2001) Essential fish habitat and the effective design of marine reserves: application for marine ornamental fishes. Aquarium Sci Conserv 3:135-150

Gasparini JL, Floeter SR, Ferreira CEL, Sazima I (2005) Marine ornamental trade in Brazil. Biodivers Conserv 14: 2883-2899

Gebauer P, Paschke K, Moreno CA (2007) Reproductive biology and population parameters of Petrolisthes laevigatus (Anomura: Porcellanidae) in southern Chile: consequences on recruitment. J Mar Biol Assoc UK 87: 729-734

Goodman LA (1965) On simultaneous confidence intervals for multinomial proportions. Technometrics 7:247-254

Gore RH (1982) Porcellanid crabs from the coasts of Mexico and Central America (Crustacea, Decapoda, Anomura). Smithson Contrib Zool 363:1-34

Gore RH, Abele LG (1976) Shallow water porcelain crabs from the Pacific coast of Panama and adjacent Caribbean waters (Crustacea: Anomura: Porcellanidae). Smithson Contrib Zool 237:1-30

Green E (2003) International trade in marine aquarium species: using the Global Marine Aquarium database. In: Cato JC, Brown CL (eds) Marine ornamental species: collection, culture, and conservation. Iowa State Press, Iowa City, IA, p 31-47

Haig J (1956) The Galatheidea (Crustacea Anomura) of the Allan Hancock Atlantic Expedition with a review of the Porcellanidae of the western north Atlantic. Allan Hancock Atlantic Expedition Report 8. University of Southern California Press, Los Angeles, CA

Hartnoll RG (1982) Growth. In: Bliss DE (ed) The biology of Crustacea: embryology, morphology, and genetics, Academic Press, New York, NY, p 11-196

Heino M, Godo OR (2002) Fisheries-induced selection pressures in the context of sustainable fisheries. Bull Mar Sci 70:639-656

Hernández G, Graterol K, Álvarez A, Bolaños J (1998) Larval development of Porcellana sayana (Leach, 1820) (Crustacea: Decapoda: Porcellanidae) under laboratory conditions. Nauplius 6:101-118

> Keunecke KA, D'Incao F, Fonseca DB (2007) Growth and mortality of Hepatus pudibundus (Crustacea: Calappidae) in south-western Brazil. J Mar Biol Assoc UK 87: 885-891

López-Victoria M, Barrios LM, Kraus H, Osorio LA (2004) New aspects on the symbiotic relationships between Dardanus fucosus (Crustacea: Paguridae), Calliactis tricolor (Cnidaria: Hormathiidae) and Porcellana sayana (Crustacea: Porcellanidae). Bol Invest Mar Cost 33: 261-264 
Matos-Caraballo D, Mercado-Porrata A (2007) Description of the ornamental fishery in Puerto Rico, 1997-2005. Proc 60th Gulf Caribbean Fish Inst 60:97-107

Meireles AL, Mantelatto FL (2008) Biological features of a puzzling symbiotic association between the hermit crab Dardanus insignis and the porcellanid crab Porcellana sayana (Crustacea). J Exp Mar Biol Ecol 362:38-42

Miranda I, Mantelatto FL (2009) Estimating population features of the anomuran crab Petrolisthes armatus (Porcellanidae) in a remaining and impacted mangrove area of the western Atlantic. J Nat Hist 43:2027-2039

> Ocampo E, Nuñez JD, Cledón M, Baeza JA (2012) Hostspecific reproductive benefits, host selection behavior and host use pattern of the pinnotherid crab Calyptraeotheres garthi. J Exp Mar Biol Ecol 429:36-46

Oliveira E, Masunari S (1995) Estrutura populacional de Petrolisthes armatus (Gibbes) (Decapoda, Anomura, Porcellanidae) da Ilha do Farol, Matinhos, Paraná, Brasil. Rev Bras Zool 12:355-371 (in Portuguese with English abstract)

Onaga T, Fiedler C, Baeza JA (2012) Prontadric simultaneous hermaphroditism in Parahippolyte misticia (Crustacea: Decapoda: Hippolytidae): implications for the evolution of mixed sexual systems in marine shrimps. J Crustac Biol 32:383-394

Osawa M, Fujita Y (2001) A new species of the genus Neopetrolisthes Miyake, 1937 (Crustacea: Decapoda: Porcellanidae) from the Ryukyu Islands, southwestern Japan. Proc Biol Soc Wash 114:162-171

Osawa M, McLaughlin PA (2010) Annotated checklist of anomuran decapod crustaceans of the world (exclusive of the Kiwaoidea and families Chirostylidae and Galatheidae of the Galatheoidea) Part II - Porcellanidae. Raffles Bull Zool 23:109-129

Pinheiro MAA, Hattorri GY (2006) Growth of the speckled swimming crab, Arenaeus cribrarius (Lamarck, 1818) (Crustacea, Brachyura, Portunidae), in Ubatuba (SP), Brazil. J Nat Hist 40:1331-1341

Reid DM, Corey S (1991) Comparative fecundity of decapod crustaceans, II. The fecundity of fifteen species of anomuran and brachyuran crabs. Crustaceana 61: 175-189

Rhyne A, Rotjan R, Bruckner A, Tlusty M (2009) Crawling to collapse: ecologically unsound ornamental invertebrate fisheries. PLoS ONE 4:e8413

Sastry AN (1983) Ecological aspects of reproduction. In:

Editorial responsibility: Raymond Bauer,

Lafayette, Louisiana, USA
Bliss DE (ed) The biology of Crustacea, Vol 8. Environmental adaptations. Academic Press, New York, NY, p 179-270

Scelzo MA (1985) Biologia y morfometria del cangrejo Petrolisthes politus (Gray, 1831) (Anomura, Porcellanidae) de la Isla Cubagua, Venezuela. Bol Inst Oceanogr Venez 24:63-74 (in Spanish with English abstract)

Shanks AL, McCulloch A, Miller J (2003) Topographically generated fronts, very nearshore oceanography and the distribution of larval invertebrates and holoplankters. J Plankton Res 25:1251-1277

> Smaldon G (1973) Some notes on the sexually dimorphic characters of Pisidia longicornis (L.) (Decapoda Anomura). Crustaceana 25:220-222

Telford M, Daxboeck C (1978) Porcellana sayana Leach (Crustacea: Anomura) symbiotic with Strombus gigas (Linnaeus) (Gastropoda: Strombidae) and with three species of hermit crabs (Anomura: Diogenidae) in Barbados. Bull Mar Sci 28:202-205

> Tlusty M (2002) The benefits and risks of aquacultural production for the aquarium trade. Aquaculture 205: 203-219

von Bertalanffy L (1938) A quantitative theory of organic growth. Hum Biol 10:181-213

- Wenner AM (1972) Sex ratio as a function of size in marine Crustacea. Am Nat 106:321-350

Werding B (1977) Los porcellánidos (Crustacea: Anomura: Porcellanidae) de la región de Santa Marta, Colombia. An Inst Inv Mar Punta Betin 9:173-214 (in Spanish with English abstract)

Werding B (1984) Porcelanidos (Crustacea: Anomura: Porcellanidae) de la Isla de Providencia, Colombia. An Inst Inv Mar Punta Betin 14:3-16 (in Spanish with English abstract)

Williams AB (1984) Shrimps, lobsters and crabs of the Atlantic coast of the eastern United States, Maine to Florida. Smithsonian Institution Press, Washington DC

Wilson K, Hardy ICW (2002) Statistical analysis of sex ratios: an introduction. In: Hardy ICW (ed) Sex ratios: concepts and research methods. Cambridge University Press, Cambridge, p 48-92

Wood EM (2001) Collection of coral reef fish for aquaria: global trade, conservation issues and management strategies. Marine Conservation Society, Ross-on-Wye

Zar JH (1999). Biostatistical analysis. Prentice-Hall, Englewood Cliffs, NJ

Submitted: January 8, 2013; Accepted: March 28, 2013

Proofs received from author(s): April 18, 2013 